\title{
EDUCATION BY THEATRE PROJECT (2010 - 2014)
}

\section{Dagmar Inštitorisová ${ }^{1}$}

\begin{abstract}
This article summarizes the almost four-year duration of the Vzdelávanie divadlom (Educating through the Theatre) project from 2010 to 2014, which was funded through European structural funds and based at the Faculty of Arts, Constantine the Philosopher University, in Nitra. This project was managed by the author. As part of the project, 27 workshops were held on historical and contemporary poetics in theatre and their application. There were 45 works published (28 monographs, 15 manuals, and 2 electronic publications) and 8 lectures, 1 colloquium, 1 international conference, and 3 school theatre productions. Eleven Slovak theatre companies were hosted and two theatre festivals supported. This article highlights the main aims of the project and its impact at a nationwide level.
\end{abstract}

UDC Classification: 378, 027.7, 7.06, DOI: http://dx.doi.org/10.12955/cbup.v4.771

Keywords: educating, the Theatre, the project, the main aims, contents, the results.

\section{Introduction}

The project, "Education by Theatre", focused on the innovation of existing forms and methods of courses in theoretical, historical, and practical education, as well as the creation of pedagogicaldidactic materials and tools of the existing education model used in theatre (including personal development by means of theatre) and drama creation and teaching at the Constantine the Philosopher University in Nitra. The project was outlined in a manner allowing the use of possible creative theatre techniques in an interdisciplinary way.

The project, Education by Theatre, was recognized at the following departments and workplaces of the Constantine the Philosopher University in Nitra:

- The Institute of Literary and Artistic Communication, Faculty of Arts;

- The Department of Cultural Studies, Faculty of Arts (including The University Creative Atelier);

- The Department of English and American Studies, Faculty of Arts; and

- The Department of Music (teaching musical-dramatic arts), Pedagogical Faculty.

Part of the process of innovating the methods and procedures for particular subjects included participation of graduates, former Doctor of Philosophy $(\mathrm{PhD})$ students, and current teachers of the Academy of Performing Arts in Bratislava, former PhD students of the Academy of Performing Arts in Brno, and active theatre artists. This emerged from the interdigitating of theatre techniques with interdisciplinary procedures and aesthetic thinking, cultural studies, and other specializations.

Project activities were recognized continuously throughout the academic year of all three years of the project duration.

The departments of Cultural Studies, Music, English and American Studies, and the Institute of Literary and Artistic Communication also participated in the project with the aim of supporting student ability to apply acquired knowledge and skills in the wider non-humanities context, improve cultural and theatre awareness, and contribute overall to approximating the graduates of the aforementioned departments for the needs of the labor market and knowledge society. The project connected research and pedagogical objectives and, by involving $\mathrm{PhD}$ students, it also offered the possibility to improve scientific and pedagogical activities at the third level of university education.

At a significant rate, the project stimulated the development of artistic activities at the Constantine the Philosopher University. Since artistic activities have specifics that require adequate financing (because of individual study plans and relatively high financial costs of materials), certain activities of the project were essential for many students.

Within the project, the departments participating, as well as the Media Centre at the Faculty of Arts of Constantine the Philosopher University, the university's library, and the University Creative Atelier, were provided with technical and material equipment.

\footnotetext{
${ }^{1}$ Dagmar Inštitorisová, Akadémia médií (Media Academy), Zámocká č. 34, 81101 Bratislava, dagmar.institorisova@gmail.com
} 
As a result of the project, departments and other facilities, such as the university's library, were able to create centers for study of theatre performances and plays through multimedia. A large number of domestic and foreign print and electronic publications on theatre were acquired also.

The recording of the course and results of particular project activities, and the production of digital versatile discs (DVDs) and compact discs (CDs), were undertaken by the media center at the Faculty of Arts of Constantine the Philosopher University and Radio Plus.

\section{The results of the project}

A series of workshops named, "Historical Theatre Poetics", evolved, of which the majority were workshops aimed at reconstructing historical theatre poetics through Sophocles' Antigone. The form of reconstruction of historical and contemporary poetics represented the pilots. Another series was named, "Contemporary Theatre Poetics", and presented procedures of contemporary drama aesthetics and practical principles from its perception (workshop on authorial drama writing, artistic direction workshop, scenographic workshop, scenic music workshop, direction workshop, acting workshop, and theatre critique). The last group was represented by "Workshops on Application of Theatre Techniques", within which the students had the opportunity of acquainting themselves with various forms of theatre techniques in the framework of interdisciplinary connections (e.g. theatre and English, and theatre and therapy).

The project resulted in various innovative educational activities, which involved working with students directly in seminars and classes. This included preparing the school performance, "The Vampire's Ball" [Ples upírov], and excursions to professional Slovak theatres.

The project archived theatre plays and performances, which included video recordings of performances in English at the drama festival for elementary and grammar schools, organized by the Department of English and American Studies.

Further, the project produced a series of publications on the history and theory of historical and contemporary theatre poetics, mainly of a monographic character. Highly appreciated, was the multimedia study book, "On Poetics of Contemporary Theatre (heuristics)", which was elaborated by regular guest appearances of theatre groups with non-traditional or innovative poetics in the University Creative Atelier of the Faculty of Arts, Constantine the Philosopher University. Theatre and guest artists were of Slovak origin.

The project was completed on May 21-22, 2013 with the international conference: "Education by Theatre", where overall results of the project were presented (Inštitorisová et al, 2013b).

The target group of the project were students including $\mathrm{PhD}$ students of aforementioned departments, and other departments of the Constantine the Philosopher University in Nitra.

A minimum of 320 student participants was planned for the project (165 students specializing in aesthetics, 65 in cultural studies, 70 in musical-dramatic specialization, and 20 in English and American studies). However, the planned number was significantly exceeded in all specializations.

The assumed age structure was 18-24 years and level of education of the students were university undergraduates, graduates of specialized high and grammar schools, and Bachelor of Arts (BA), and $\mathrm{PhD}$ students.

The activities, study, and work materials for students were continuously published on the website of the project: www.vzdelavaniedivadlom.ukf.sk, under the following sections: Workshops > new, Workshops > archives, Publications, Musical, Other Activities (designed for announcements on guest appearing of drama groups in University Creative Atelier, about lectures, excursions, and festivals), Presentations, and Publicity and Materials for Students. Another, designed for administration of the project, was called Administration.

Materials for students were elaborated upon according to sources from lectors of particular workshops and then supplemented by the supervisor of the project for other needed aspects. These were then presented as basic or recommended literature as well as working materials used during practical realization of the workshops. Materials were available to all participants of all workshops, not only to a student participating at a particular workshop. Materials were protected by password for students as well as administrators of the project. 
Each workshop had a public presentation of its results, introduced with the cooperation of the lectors and students. This included demonstrations of authorial performances, proposals of scenographic solutions, and types of music for theatre performances. Lectors also explained the objectives of particular workshops.

The form of a workshop is well-known, but in the project it was used in a rather untraditional way. On one hand, it was innovating in terms of the teaching process, while on the other it was optimizing in respect of being educational in a wider context, since the results of the workshops were always presented in the form of a publication. By publishing the case regarding essential Slovak theatrological literature, the workshop was optimized, though it suffered from an absence of domestic literature in some areas (that related to translation of literature) and little challenge in the theatre- educational environment (e.g. absence in the departments of creative dramatics and theatrology and similar areas).

Propagation of the project and its results and progress was provided through the website of Constantine the Philosopher University in Nitra: www.ukf.sk, and the website of the Faculty of Arts: www.ff.ukf.sk. Other means of propagation included publications, monographs, methodology, DVD demonstrations, and conferences.

The response to particular activities was provided by students and participants of workshops, who published their opinions, experiences, and interviews with lectors, in both the printed and electronic media, such as "Občas NEČAS" (www.obcasnecas.ukf.sk), "Redakcia" (artblog.sk/redakcia), and other similar online sites, or in professional journals, such as "Javisko" and "kød".

Complexities in innovation of subjects on theatre education, as well as the conception of publicity, were considered the basis for stimulating the attractiveness of the project for students, including $\mathrm{PhD}$ students.

The project involved two basic activities (as specified in the project structure of the European Social Fund). These primary objectives were activities 1 and 2 and their sub-activities 1.1 and 2.1, as follows:

1. Improvement of the quality and competitiveness of Constantine the Philosopher University in Nitra via introduction of innovative forms of education;

1.1. Innovation of forms and methods of courses on theoretical, historical and practical education;

2. Support of the rationalization and improvement of quality of the teaching process of study programs in theatrological disciplines;

2.1. Elaboration of pedagogical-didactic materials and tools.

An addendum to 1.1 stated that the aims of the activity were innovation, development and creativities of teaching, and their interdisciplinary application.

The activity transformed the model of education by theatre (including personal development by means of theatre), drama creation and education, and the preparation of a project that was realized at three Faculties of Constantine the Philosopher University in Nitra: the Institute of Artistic and Literary Communication and Department of Cultural Studies at the Faculty of Arts, the Department of Music (didactics of music-dramatic arts) at the Pedagogical Faculty, and the Department of English and American Studies at the Faculty of Arts. The innovated model was aimed at the theoreticalmethodological and pragmatic innovation of subjects of a historical and theoretical character as well as improvement of quality and the broadening of topics and procedures used in creative and reception seminars, so that creative theatre techniques might be used in an interdisciplinary way.

A partial aim of the activity was to prepare teachers of the Institute of Artistic and Literary Communication for the institute's possible requalification into a center for high school teachers that introduced a new subject of art and culture, of which theatre or education by theatre might be a part.

Innovation of the forms and methods of courses in theoretical, historical, and practical education contained:

a) Workshops (realization during seminars and lectures on history and theory of world and domestic theatre aimed at historical and contemporary theatre poetics and their application in non-theatre contexts, which were also provided by workshops in The University Creative Atelier and other premises of Constantine the Philosopher University in Nitra);

b) Creativities, development, and optimization of pedagogical procedures at seminars and lectures on history of world and Slovak theatre, theory of theatre (including seminars on interpretation 
of drama work, theory of drama creation, genres of drama, stage techniques, and scenography), and theatre creation and methodology (creative dramatics and a creative seminar with theatre and acting creation, musical dance, movement education, didactics, and other similar activities);

c) Rehearsing the school musical performance, The Vampire's Ball; and

d) Other educational activities for students including $\mathrm{PhD}$ students (e.g. lectures by domestic lecturers, colloquium, and a conference).

\section{Workshops}

The basis of the workshops was to attempt to innovate forms and methods of engagement at seminars and lectures regarding world and domestic theatre and the theory of theatre within the aforementioned subjects. Most important was the broadening of creative (such as theatre workshops) or theoretical seminars (such as interpretation of theatre work) in several workshops for up-to-date poetics and aspects of the aesthetics of contemporary theatre procedures. The broadening and innovation focused mainly on: authorial playwriting, acting and scene design techniques, and others in the form of directing, writing, artistic directing, acting, scene design and music workshops, and workshops on dramatics.

As stated above, the workshops were realized on three basic lines:

- Historical theatre poetics;

- Contemporary theatre poetics; and

- Workshops on application of theatre techniques.

The basis of the series of workshops on historical and contemporary theatre poetics was always work with a drama text, either a historical or contemporary one. In the case of the series, "Historical Theatre Poetics", it was Sophocles' Antigone, and in the case of the "Contemporary Theatre Poetics", it was the drama text "P" by contemporary Slovak playwright, Dano Majling (2010).

The aim of the defined topic was to bring the participants of the workshops closer to understanding the language of the theatre in any temporal context. The very well-known text from the historical poetics enabled immediate uptake and more effective work under the basic meaning of the text (the so-called actual semantic layer of the text) as well as a higher quality and depth of performance techniques. As a result of being introduced to the basic plot of the play, students found concentrating was easier, not only with "exploring" the theatre of ancient Greece, but also in terms of more freely approaching the quest for opportunities to reconstruct historical performance poetics in modern theatre contexts. In the case of the workshop series, "Contemporary Theatre Poetics", the choice of a play by a contemporary author helped the students to understand the poetics of the play through its contemporariness. Searching for theatrical representation through basic performance aspects (artistic, acting, scene design, direction, and other expressive means) could thus introduce theatre specifics of those aspects. The choice of the aforementioned procedure was very often influenced by students having or only recently gaining a basic knowledge on history and theory of theatre.

The course and result of all workshops were recorded on DVD and their presentation became part of numerous publications, such as methodologies that emerged after the workshops. These methodologies represented the aims, methods, and means used for achieving the workshops. Authors of the publications (methodologies) were leaders of the workshops. The results of the workshops in the form of publications can be later used and developed in educational processes and other interdisciplinary areas (e.g. theatre and creativity, therapy, rhetoric, aesthetics, literature, and visual arts).

The most crucial workshop in the series, "Historical Theatre Poetics", was aimed at the reconstruction of the theatre poetics of "Antigone" at the University Creative Atelier. During these workshops several activities related to the understanding of topical theatre aesthetics, and contemporary theatre aesthetics were conducted (e.g. lecture on ancient Greek theatre, a workshop on scene design aimed at the performance of ancient Greek theatre, a dance and music workshop, and a workshop on the direction and artistic direction of Antigone).

Based on all workshops that were focused on Antigone, a publication by Inštitorisová et al. (2013a; Antigone - the Unfinished "Theatrology") with DVD samples of "reconstructions" of the performance techniques of ancient Greek theatre was developed. Together with the trilogy, "Oedipus the King, 
Antigone and Oedipus at Colonus", and other documents, it offered a higher quality pedagogical and scientific approach to the area.

The Contemporary Theatre Poetics series of workshops contained workshops thematically aimed at traditional and contemporary aesthetics of particular theatre-performance elements (scene design, direction, acting, and similar aspects). Emerging from these workshops were several elaborated publications. These explained the basic terms of theatre poetics in a historical and contemporary context (for example, a directional workshop: casting and mise-en-scene; and an acting workshop: character and acting action). When applying the publications to particular subjects it will be possible to apply the procedures to other situations as well as create new procedures in contemporary theatre poetics. Authors of this type of publication were leaders of the workshops.

\section{Creativities, development, and optimization of teaching processes}

In this part of the project, the main focus was about establishing new or innovated forms and methods of education. The important component was broadening techniques for new creative forms to enable flexible operation of the knowledge and skills gained. The new and innovated forms were aimed at the ability of students to apply the forms to other situations related to history and theory of theatre and the area of methodology of theatrological disciplines. The innovation of the aforementioned educational model of historical and contemporary theatre poetics in a theoretical, historical, and practical context was particularly significant. For example, with teaching historical theatre poetics at seminars on history of world theatre, the form for reconstructing historical poetics can be used (or contemporized). This might offer the opportunity to gain, not only knowledge on particular poetics, but also particular creative activities, e.g. direction, scene design, or procedures of certain poetics through use of its strategies and techniques in smaller activities (e.g. for topics on history or theory of theatre).

Within the series on Contemporary Theatre Poetics, the main focus was about encompassing the "living" theatre in its rich forms and methods through performances of visiting theatre groups at The University Creative Atelier at the Faculty of Arts, Constantine the Philosopher University. The performances were recorded on a DVD, which was attached to the multimedia study book by Inštitorisová et al (2013d), "On Poetics of Contemporary Theatre (Heuristics)". Apart from the recordings of performances that were made with the approval of the authors, all recordings contained rich heuristic material aimed at the poetic characteristics of the performance and theatre group. The electronic study book thus introduces a model of elementary theatrological research material for analysis of poetics of any theatre text.

Another aspect for increasing the efficiency of education processes was the creation of archives of theatre plays and performances, which contained video and DVD recordings of the performances, as well as scans of theatre plays and other documents and materials with theatrological topics. The archives will become the basic study tool, mainly at seminars on history of theatre, though they might well find use in other subjects.

\section{Training and preparation of the school musical performance, Vampire's Ball}

The school musical performance, the "Vampire's Ball", was realized during the academic year 2010 2011. Its first and second premiere took place on May 3 and 4, 2011 at 6.30pm at the Karol Spisak Old Theatre in Nitra. It was created during the music-dramatic specialization at the Department of Music at Pedagogical Faculty (in cooperation with the Faculty of Arts), which, being the only one in Slovakia, provided a specialization for teaching in the field of music-dramatic arts. The study program of the department is aimed at the integration of music, dance and drama arts, and their pedagogical application in music-drama education at elementary schools of art and leisure centers. Within the preparation for their future profession, the students have the opportunity to develop their skills in music-drama performance at the Karol Spisak Old Theatre and Andrej Bagar Theatre in Nitra, which regularly provide amenities for several subjects of the Department of Music.

The main aim of the rehearsal and preparation of the school musical performance was to:

- actively integrate students, pedagogues, and workers of Constantine the Philosopher University in Nitra for preparation, creation, and rehearsal of the musical;

- develop the talent, skills, and practical experience of music-drama students through musical training; 
- perform the musical performance with live orchestra, choir, and children's choir, since musicals in Slovakia have no longer been presented in this way; and

- enable the emergence of school musical performance in optimal financial and technical conditions.

The course for training and preparing the play was recorded on DVD, which will serve as working material for students and teachers of the Department of Music as well as others. Together, with the methodology of Inštitorisová et al (2012b), "How The Vampire's Ball Musical Was Created", it has become the basic study material for clarifying the process of emerging musical and explaining poetics, and expressive means of the musical. The publication deals with the performance model of a contemporary musical.

Costume, scene, and technical equipment that were created or gathered within the project became part of the archive of costumes and scene equipment of the Department of Music and will remain in use for further teaching processes.

Within the project, other theatre projects were supported. These projects were elaborated at the student's theatre, Vydi, at Faculty of Arts, Constantine the Philosopher University in Nitra. The support was realized in the form of workshops of the name: "How Is a Theatre Performance Made I., II.", which symbolizes their main focus, i.e. to bring the theatre closer to students who do not study at artistic theatre academies. The results of these workshops included two students' performances: "Mind (the) Body" (premiere: February 27, 2013) and "From the East to the West" (premiere: April 23, 2013). The first performance received a significant award in that it became a laureate at the competition of university students at the Academy of Presov in 2013.

Both performances were presented in the evening for members of the international conference, Education by Theatre at the University Creative Atelier.

\section{Other educational activities for students including PhD students}

The aim of this part of the project was to create a challenging environment that would increase students' interest in $\mathrm{PhD}$ study on a particular theatrological specialization as well as theoretical, historical, and practical theatre subjects at Constantine the Philosopher University in Nitra. The foundation had been provided by domestic lecturers and current and former $\mathrm{PhD}$ students of the author of the project. This part of the activity was closely connected with publishing activities of $\mathrm{PhD}$ students and other students of the author of the project (including PhD students: Daniel Uherek, Peter Janků, Matej Šiška, Peter Oravec, Miroslav Ballay, and Iveta Škripková; and other students: Katarína Dudová, Petra Pappová, Michaela Malíčková, Petra Kaizerová, and Peter Zlatoš), together with material and technical equipment of the educational facilities and workshops. A large number of publications emerged (not only) on the basis of $\mathrm{PhD}$ and other research theses of the $\mathrm{PhD}$ students and other students of the author of the project.

The Institute of Literary and Artistic Communication broadened its $\mathrm{PhD}$ educational activities for external institutions, e.g. the Cabinet of Theatre and Film of Slovak Academy of Sciences in Bratislava and project activities aimed at $\mathrm{PhD}$ students to improve the quality of $\mathrm{PhD}$ studies in these institutions.

Within some activities of the project, the possibilities of using certain results were tested in an interdisciplinary context. These were related mainly to themes of theatre and creativity (aimed at personal development), theatre and therapy (aimed at use of theatre techniques in a psychological context), and others (for example the Artery workshops: Drama Therapy in Practice or Therapy by Theatre).

Within this activity, the project interconnected in an organizational and cultural way with the Andrej Bagar Theatre in Nitra and Karol Spisak Old Theatre in Nitra. For example, a former actor of the Andrej Bagar Theatre led the workshop on acting.

A major success of the project was that of the project photographer, Lukasz Wojciechowsky, $(\mathrm{PhD}$ student of the author of the project) in the first year of the competition, Biennale of Theatre Photography, 2012. This student won the Grand Prix for his photographs of the performance, "The Bride of the Ridge" [Nevesta hôl'] by the Theatre Pôtoň group. The photographs were taken during the theatre group's visit at the University Creative Atelier theatre, within the activities of the project. The 
award-winning photographs have thus far been exhibited three times, in the facilities of the Opera House of the Slovak National Theatre in Bratislava, during the exhibition of "The Light that Means the World" (Svetlo, ktoré znamená svet) in the Mlyny gallery in Nitra, and during the international conference, Education by Theatre at the University Creative Atelier.

A particularly significant success emanating from the students' activities was, not only their attendance at the workshops or the possibility to learn how to write about theatre, but the successful participation of an active participant of the project workshops, Denisa Polúchová, at the Academy of Arts in Prague, Department of Educational Dramatics (specialization drama education). Denisa is a BA graduate from the music-dramatic specialization at the Department of Music of Pedagogical Faculty, Constantine the Philosopher University in Nitra. Within the project, as a "student", she prepared three workshops, collectively entitled Theatre Forum, and introduced these to the Slovak theatre community for the first time. Another project workshop participant, Lucia Holienčinová, established her own theatre group. The $\mathrm{PhD}$ and other students actively participated in the international conference, Education by Theatre, with some publishing their final theses in the form of a collective monograph.

With huge interest, the students attended the excursions of the theatres around Slovakia (Žilina, Martin, and east Slovakia), which were organized annually during the project. Apart from the last excursion to theatres in the east of Slovakia, the excursions were always attended by more than 90 students.

\section{Creation of pedagogic-didactic materials and tools}

The aim of the activity was to improve quality, optimize and modernize existing tools, and support the rationalization of the theatre educational process in various study programs at Constantine the Philosopher University in Nitra.

Currently, the university environment dedicates little attention to theatre education in any context and for a rather long time no conferences have been organized that focused on this area (or other forms of discussion). There is still an absence of methodological expert and scientific material over a rather large area of themes that could reflect, deepen, and develop the contemporary state of theatre reflection or similar disciplines (e.g. theory performance, scenology, theory of authorial theatre, and theory of scene music).

The problem of innovation in education by theatre is related to the aforementioned absence, and this evokes the impression that there is no difference between theatrical, performative, or interactive actions of human beings or forms of their actions. The project therefore provided a number of publications that deal with such questions in a direct and indirect way. Also related to these problems were the workshops and innovation of procedures during the theoretical, historical, and practical subjects, of which results were recorded either on DVD or in writing.

Within this activity series, pedagogical-didactic material and tools were created. A number of published results were delivered in multimedia formats. Monographs with materials on DVD or CD and all methodologies will enable the development of activities and application of processes used in new situations, to vary them, and practically develop the topics of historical poetics towards the conte mporary.

Within the historical poetics, publishing activities were aimed at filling gaps in the history of theatre, e.g. the monograph on Sophocles (Borodovčáková, 2013), or dramatics in the magazine, the Sorcerer, or Sophocles' Antigone.

The situation is similar in the case of contemporary theatre aesthetics. Because of the absence of publications of crucial importance, the publishing activities of the project were aimed at publishing study materials (monographs and methodologies) of crucial importance in specific areas of theatrology, e.g. the monograph on French playwright Koltès (Uherek, 2012), theatre studio Farm in the Cave (Ballay, 2012), English playwright S. Kane (Kratochvilová, 2013), theatre translation (Janecová et al, 2013; Šebesta, 2013; Gromová, Hodáková, Janecová, Müglová \& Filípková, 2013), and artistic direction, scene design, and scene music (Pavlac, 2012; Pavlac, 2013; Piaček, 2012; Král', 2013; Janků 2013; Benčík, 2013; Dušová, 2013; Žiška, 2013; Dubačová, 2013; Blašková, 2013; Olšiak, 2013; Čajková, 2013; Inštitorisová, 2013b). Their application is rather wide, mainly in areas of history of arts, history, history and theory of literature, and history and theory of music. The 
publications are already used and are part of the basic and recommended bibliography for $\mathrm{PhD}$ and other students.

Almost all publications, except second editions (Inštitorisová et al, 2012a; Inštitorisová et al, 2013c; Inštitorisová, 2013d), which were developed within the publishing activities of the project, have a unique position within the Slovak theatrological bibliography. They are all first editions on the topics that focus on various subjects (Oravec, 2012; Janků, 2012; Piaček, 2013; Bačová, 2013; Bačová, Bílliková \& Kiššová, 2013; Bílliková \& Kiššová, 2013; Maliti, 2013; Malíčková, 2013; Šiška, 2013; Škripková, 2013; Pappová 2013a; Pappová 2013b; Pappová et al., 2013; Hrašková, 2013; Dudová, 2013; Kaizerová, 2013; Inštitorisová, 2013a; Inštitorisová, 2013c). Also unique were the many participants that were contemporary theatre creators who rarely contribute to academic publications. Their results, however, are equal to those emerging from the typical reception-oriented methodologies.

Within the new techniques, the use of contemporary and traditional audiovisual didactic tools, such as recordings, samples from theatre performances, use of power point presentations, and watermarks) was broadened and improved in quality.

The results of the activity included the following study materials:

- Monographs, methodologies, and others from history and theory of historical theatre poetics; and

- Monographs, methodologies, and others from history and theory of contemporary theatre poetics (including their application to various areas). A part of this range includes the aforementioned multimedia study book.

\section{Conclusion}

The results of this project are accessible to all concerned groups, and this fulfills the main aim of the project, i.e., to optimize the educational situation in Slovakia. The possibilities of transferring all results involve public accessibility (public presentations and publishing the innovative results in the form of multimedia publications) to enable further development of specific techniques and their application in new subjects. Results of the output will support the ability of students to study in a way that is creative and aimed at developing competences. The outputs develop and improve competences, such as cultural awareness and expression, and creative expression of emotions, thoughts, and skills. They also develop initiative, problem-solving, the evaluation of risks, the ability to create strategies, plan and adopt resolutions, and solve emotions in a constructive way as well as improve basic competences in the area of science and research.

The direct continuation of results involves using innovative techniques in the education of theatre subjects. After completing the project, activities (workshops on theatre and creativity and authorial drama writing) will be offered within a wider range of subjects at Constantine the Philosopher University in Nitra. This offer will include distributing publications to libraries and pedagogicalmethodological centers, the results serving as a foundation for innovating the departmental archives (e.g., archive of innovative education processes). It will also include long-term cooperation between various institutions (e.g., Constantine the Philosopher University in Nitra, Academy of Performing Arts in Bratislava, and Academy of Performing Arts in Prague). This can help systemize and deepen interest in theatre education at universities, with the results available for $\mathrm{PhD}$ students at other universities. Long-term positive effects for the target group include gaining competences of students (including PhD students), providing more effective involvement in practical applications (pedagogical or other practice), increasing flexibility, higher ability to gain new knowledge, better orientation in knowledge, creation of new solutions, and increased independence in the labor market.

All new educational facilities, after completion of the project, will be available for intensive use by students of Constantine the Philosopher University in Nitra. This includes facilities of The University Creative Atelier and the Media Centre at the Faculty of Arts, Constantine the Philosopher University in Nitra. Furthermore, students will be able to use archival materials for afterschool activities, e.g., work in amateur theatre groups, and after completing their university studies, as teaching tools in their own pedagogical or other practice.

\section{References}

Bačová, D. (2013). British Women Dramatists of the Second Half of the Twentieth Century [Britské dramatičky druhej polovice 20. storočia]. Nitra, Slovakia: Constantine the Philosopher University in Nitra. 
Bačová, D., \& Bílliková, A., \& Kiššová, M. (2013). Drama Techniques and their Potential in Foreign Language Teaching [Dramatické techniky a ich potenciál vo výučbe cudzích jazykov]. Nitra, Slovakia: Constantine the Philosopher University in Nitra.

Ballay, M. (2012). Farm in the Cave [Farma v jeskyni]. Nitra, Slovakia: Constantine the Philosopher University in Nitra.

Benčík, J. (2013). A Little Course on Pantomime [Malá škola „pantomíma“]. Nitra, Slovakia: Constantine the Philosopher University in Nitra.

Bílliková, A., \& Kiššová, M. (2013). Drama Techniques in Foreign Language Classroom. Nitra, Slovakia: Constantine the Philosopher University in Nitra.

Blašková, L. (2013). Performance Activities with Educational Impact [Performačné aktivity s edukačným presahom]. Nitra, Slovakia: Constantine the Philosopher University in Nitra.

Borodovčáková, M. (2013). Sophocles [Sofokles]. Nitra, Slovakia: Constantine the Philosopher University in Nitra.

Čajková, J. (2013). From Recitation to Theatre [Od umeleckého prednesu k divadlu]. Nitra, Slovakia: Constantine the Philosopher University in Nitra.

Dubačová, V. (2013). Therapy by the Theatre [Terapia divadlom]. Nitra, Slovakia: Constantine the Philosopher University in Nitra.

Dudová, K. (2013). The Cognitive Scheme Source - Journey - Goal in the Language of Dramatic Text [Cesta k nadčasovým hodnotám cez jazyk dramatického textu). Nitra, Slovakia: Constantine the Philosopher University in Nitra.

Dušová, P. (2013). The Story of a Puppeteer about Puppet Acting [Rozprávanie bábkoherca o herectve s bábkou]. Nitra, Slovakia: Constantine the Philosopher University in Nitra.

Gromová, E., \& Hodáková, S., \& Janecová, E., \& Müglová, D., \& Filípková, A. (2013). Translation in Theatre Communication [Translácia v divadelnej komunikácii]. Nitra, Slovakia: Constantine the Philosopher University in Nitra.

Hrašková, M. (2013). Biblical Themes in Slovak Drama [Biblické témy v slovenskej dráme]. Nitra, Slovakia: Constantine the Philosopher University in Nitra.

Inštitorisová, D. (Ed.), Sprušanský, S., Varnas, G., Grusková, A., Gáborová, A., Kuffelová, A., Majeský, M., Hrčka, J., Zelmanová, M., Hvišč, M., Čavojský, L., Ballay, M., Uherek, D., Janků, P., Fuják, J., Kapsová, E. (2012a). August Strindberg the Dream Play [August Strindberg Hra snov (interpretačné sondy do slovenského divadla)]. Nitra, Slovakia: Constantine the Philosopher University in Nitra.

Inštitorisová, D. (Ed.), Oravec, P., Civáňová, S., Štrasser, J., Janecová, E., Štrbák, M., Záhoráková, E., Janků, P., Kleinová, E., Hyža, J., Musil, D. (2012b). How The Vampire's Ball Musical Was Created [Ako vznikal muzikál Ples upírov]. Nitra, Slovakia: Constantine the Philosopher University in Nitra.

Inštitorisová, D. (Ed.), Libiaková, V., Dubačová, V., Kovalyk, U., Krebs, P., Daubnerová, S., Laciaková, D., Škripková, I., Benčík, J., Durčeková, M., Dedíková, L., Polášová, D. (2013d). On Poetics of Contemporary Theatre (Heuristics). [K poetike súčasného divadla (heuristika)]. Nitra, Slovakia: Constantine the Philosopher University in Nitra.

Inštitorisová, D. (2013a). Critically about Theatre [Kriticky o divadle]. Nitra, Slovakia: Constantine the Philosopher University in Nitra.

Inštitorisová, D. (2013b). Theatre Critique [Divadelná kritika]. Nitra, Slovakia: Constantine the Philosopher University in Nitra.

Inštitorisová, D. (2013c). On the Education by Theatre Project [O projekte Vzdelávanie divadlom]. Nitra, Slovakia: Constantine the Philosopher University in Nitra.

Inštitorisová, D. (2013d). On Expressive Variability of a Drama Work [O výrazovej variabilite divadelného diela]. Nitra, Slovakia: Constantine the Philosopher University in Nitra.

Inštitorisová, D., Čiripová, D., Zlatoš, P., Paraličová, D., Pariláková, E., Režná, M., Michalec, M., Žilková, M., Borodovčáková, M., Dudová, K., Zeleňáková, H., Pavlac, P., Janků, P., Piaček, M., Vlčeková, S., Vajdička, M. (2013a). Antigone - the Unfinished "Theatrology"[Antigona - nedokončená "tetralógia"]. Nitra, Slovakia: Constantine the Philosopher University in Nitra.

Inštitorisová, D. (Ed.), Bačová, D., Ballay, M., Blašková, L., Ďuricová, K., Hájek, T., Králiková, M., Kopčáková, S., Kubička, T., Kušnírová, E., Laurinčíková, Z., Macková, S., Malíčová, M., Moravčík, J., Nota, J., Olšiak, M., Pechová, A., Pietrewicz, M., Pukan, M., Škripková, I., Šuda, S., Tischler, L., Vitézová, E., Zlatoš, P. (2013b). Education by Theatre [Vzdelávanie divadlom]. Nitra, Slovakia: Constantine the Philosopher University in Nitra.

Inštitorisová, D. (Ed.), Roubal, J., Šabík, V., Novosád, F., Jurkowski, H., Hořínek, Z., Kluvanec, M., Fuják, J., Bergman, A., Uherek, D., Kapsová, E., Žilková, M., Čárska, E., Dušová, P., Gogolová, D., Sabová, J., Čajková, J., Janků, P., Malíček, J., Oravec, P., Ballay, M., Malíčková, M., Plesník, L., Pukan, M., Pavlovič, J., Čiripová, D., Lindovská, N., Bačová, D., Gálová, D., Wojciechowski, L. (2013c). Theatre - Interactivity, Performance, Discourse [Divadlo - interaktivita, incenovanost', diskurz]. Nitra, Slovakia: Constantine the Philosopher University in Nitra.

Janecová, E., Gromová, E., Borodovčáková, M., Bžochová-Wild, J., Král'ová, B., Tašká, A., Ruppeldtová, O., Cviková, J., Štrasser, J., Richtera, M., Hubinák, Petáková, M. (2013). Translation and Theatre. Creative Reflections upon Translation 2 [Preklad a divadlo. Tvorivé prekladatel'ské reflexie 2]. Nitra, Slovakia: Constantine the Philosopher University in Nitra.

Janků, P. (2012). Stage Thinking [Scénické myslenie]. Nitra, Slovakia: Constantine the Philosopher University in Nitra.

Janků, P. (2013). Scenography for Non-scenographers [Scénografia pre nescénografov]. Nitra, Slovakia: Constantine the Philosopher University in Nitra. 
Kaizerová, P. (2013). Humour and Dramatics in Magazine the Sorcerer [Humor a dramatika v časopise Černokňažník]. Nitra, Slovakia: Constantine the Philosopher University in Nitra.

Král', M. (2013). A Little Guide through the World of Drama [Malý sprievodca hereckým svetom]. Nitra, Slovakia: Constantine the Philosopher University in Nitra.

Kratochvílová, D. (2013). Sarah Kane. [Sarah Kane]. Nitra, Slovakia: Constantine the Philosopher University in Nitra.

Majling, D. (2010). "P". (A variation on the themes of R. Olos's narratives Cave, Leopoldov and back and Out of sorts) ["P" (Variácie na motívy poviedok R. Olosa Jaskyňa, Leopoldov a spät’ a Vo svojej koži)]. [Manuscript. Scenario].

Malíčková, M. (2013). Vampire as a Mask of Otherness - From a Monster to the Civilized Defenders of Humanity [Upír ako maska inakosti. Od netvora k civilizovaným ochrancom l'udskosti]. Nitra, Slovakia: Constantine the Philosopher University in Nitra.

Maliti, R. (2013). Dramatist Olya Muchina and New Russian Drama [Dramatička Ol’a Muchina a nová ruská drama]. Nitra, Slovakia: Constantine the Philosopher University in Nitra.

Olšiak, M. (2013). Orthoepy of the Stage Speech [Ortoepia javiskovej reči]. Nitra, Slovakia: Constantine the Philosopher University in Nitra.

Oravec, P. (2012). Expressive Means in a Musical [Výrazové prostriedky muzikálu]. Nitra, Slovakia: Constantine the Philosopher University in Nitra.

Pappová, P., Berrio, A. G. , Zuvillaga de, J. N., Caballero, E., Fuentes, V., Iborra, M. (2013). Lope de Vega: The New Art of Writing Comedies in Our Time [Lope de Vega. Nové umenie ako písat’ komédie v dnešných časoch]. Nitra, Slovakia: Constantine the Philosopher University in Nitra.

Pappová, P. (2013a). Female Characters in Drama by Federico García Lorca [Ženské postavy v dramatickej tvorbe Federica García Lorcu]. Nitra, Slovakia: Constantine the Philosopher University in Nitra.

Pappová, P. (2013b). Theatre Thinking in 20th and 21st Century Spain [Divadelné myslenie v Španielsku]. Nitra, Slovakia: Constantine the Philosopher University in Nitra.

Pavlac, P. (2012). A Cursed Dramatist or How to Try to Get Rid of Suffering by Writing a Drama [Prekliaty dramatik alebo ako sa pokúsit' zbavit' útrap pri písaní dramatického textu]. Nitra, Slovakia: Constantine the Philosopher University in Nitra.

Pavlac, P. (2013). A Useless Dramaturg or How to Justify One's Profession (A Handbook for the Perplexed). [Zbytočný dramaturg alebo ako obhájit' svoju profesiu (Metodika pre pochybujúcich)]. Nitra, Slovakia: Constantine the Philosopher University in Nitra.

Piaček, M. (2012). Stage Music in Real Time [Scénická hudba v reálnom čase]. Nitra, Slovakia: Constantine the Philosopher University in Nitra.

Piaček, M. (2013). Music as an Event [Hudba ako udalost']. Nitra, Slovakia: Constantine the Philosopher University in Nitra.

Šebesta, J. (2013). A Day-to-night Journey through a Translation [Cesta prekladu dlhým dňom do noci]. Nitra, Slovakia: Constantine the Philosopher University in Nitra

Šiška, M. (2013). Karol Spišák's Old Theatre in the Nitra and Regional Culture [Staré divadlo Karola Spišáka v Nitre a regionálna kultúra]. Nitra, Slovakia: Constantine the Philosopher University in Nitra.

Škripková, I. (2013). The Contexts of Author's Puppet Theatre - Men's and Women's Searching in the Banská Bystrica Theatre [Kontexty autorského bábkového divadla (mužské a ženské hl'adanie v banskobystrickom divadle)]. Nitra, Slovakia: Constantine the Philosopher University in Nitra.

Uherek, D. (2012). Koltès - World Dramatist in Crisis [Koltès - dramatik sveta v kríze]. Nitra, Slovakia: Constantine the Philosopher University in Nitra.

Žiška, K. (2013). About the Theatre Directing [O divadelnej réžii]. Nitra, Slovakia: Constantine the Philosopher University in Nitra.

\section{Appendix}

Resumé of activities

Workshops

1. Introduction to creative dramatics (series of workshops on application of theatre poetics)

Date: 12. 11. 2010 - 14. 11. 2012

Lector: Mgr. art. Lucia Kovalčíková

2. Authorial playwriting (series of workshops on contemporary theatre poetics)

Date: 15. 11. 2010 - 28. 1. 2011

Lector: doc. Mgr. art. Peter Pavlac

3. Artistic direction workshops (series of workshops on contemporary theatre poetics)

Lector: doc. Mgr. art. Peter Pavlac

Date: 28, 3, 2011 - 9, 5, 2011
4. Workshops on scene music (series of workshops on contemporary theatre poetics)

Lector: Mgr. art. Marek Piaček, ArtD

Date: 8. 4. 2011 - 10. 4. 2011

5. Scene design workshops (series of workshops on contemporary theatre poetics)

Lector: Mgr. Bc. Peter Janků, PhD

Date: 6. 5. 2011 - 8. 5. 2011

6. Acting workshops (series of workshops on contemporary theatre poetics)

Lector: Mgr. art. Miloslav Král'

Date: 14. 10. 2011 - 16. 10. 2011 
7. Antigone I. - direction-dramatic analysis (series of workshops on historical theatre poetics)

Leaders: Mgr. Dáša Čiripová, doc. Peter Pavlac, Mgr. art. Michal Vajdička

Date: 9. 12. 2011 - 10. 12. 2012

8. Theatre Critique (series of workshops on contemporary theatre poetics - reception)

Leader: prof. PhDr. Dagmar Inštitorisová, PhD

Date: 16. 12. 2011 - 18. 12. 2011

9. Antigone II. - reconstruction of scene expression (series of workshops on historical theatre poetics)

Leader: Mgr. Bc. Peter Janků, PhD

Date: 17. 2. 2012 - 19. 2. 2012

10. Artistic recitation, theatre and practice (series of workshops on application of theatre poetics)

Leader: Mgr. Jaroslava Čajková

Date: 29. 3. 2012 - 1. 4. 2012

11. Antigone III - reconstructions of scene music and choreography (series of workshops on historical theatre poetics)

Leaders: Mgr. art. Stanislava Vlčeková, Mgr. art. Marek Piaček, ArtD

Date: 13. 4. 2012 - 15. 4. 2012

12. Drama and its potential in foreign language teaching (series of workshops on application of theatre poetics)

Leaders: Mgr. Andrea Bílliková, PhD, PhDr. Mária Kiššová, PhD

Date: 17. 4. 2012

13. Antigone IV. - reconstruction of aesthetics of the performance (series of workshops on Historical theatre poetics)

Leaders: Mgr. art. Michal Vajdička, doc. Mgr. art. Peter Pavlac

Date: 28. 4. 2012 - 29. 4. 2012 a 5. 5. 2012 - 7. 5. 2012

14. How is a performance made I. (series of workshops on Contemporary theatre poetics)

Leaders: doc. Mgr. Miroslav Ballay, PhD, Mgr. Boris Belica, Eva Priečková

Date: 1. 6. 2012 -3. 6. 2012

15. How is a performance made II. (series of workshops on Contemporary theatre poetics)

Leader: doc. Mgr. Miroslav Ballay, PhD

Date: 8. 6. 2012 - 10. 6. 2012

16. Theatre education (series of workshops Application of theatre poetics)

Leader: Mgr. Art. Lucia Kovalčíková

Date: 28. 9. 2012 - 30. 9. 2012

17. Drama techniques and their application in English teaching (series of workshops Application of theatre poetics)

Leaders: Mgr. Andrea Bílliková, PhD, PhDr. Mária Kiššová, $\mathrm{PhD}$

Date: 10. 10. 2012

18. Therapy by Theatre I. (series of workshops Application of theatre poetics)

Leader: Mgr. Art. Viera Dubačová

Date: 12. 10. 2012 - 14. 10. 2012
19. Artery - drama therapy in social practice (series of workshops Application of theatre poetics)

Leader: Mgr. Art. Patrik Krebs

Date: 26. 10. 2012 - 28. 10. 2012

20. Pantomime workshops (series of workshops on Contemporary theatre poetics)

Leader: Mgr. art. Juraj Benčík

Date: 9 - 11. 11. 2012

21. Puppet acting workshops (series of workshops on Contemporary theatre poetics)

Leader: Mgr. art. Petronela Dušová

Date: 23 - 25. 11. 2012

22. Directing workshops (series of workshops on Contemporary theatre poetics)

Leader: Mgr. art. Kamil Žiška

Date: 7 - 9. 12.2012

23. Homo ludens (series of workshops Application of theatre poetics)

Leader: Mgr. art. Lucia Blašková

Date: 11.10 - 13. 10. 2013

24. Theatre forum I. (series of workshops on Contemporary theatre poetics)

Leader: Bc. Denisa Polúchová

Date: 25 - 27. 10. 2013

25. Therapy by Theatre II. (series of workshops Application of theatre poetics)

Leader: Mgr. Art. Viera Dubačová

Date: 29.11 - 1. 12. 2013

26. Theatre forum II. (series of workshops on Contemporary theatre poetics)

Leader: Bc. Denisa Polúchová

Date: 29. 11 - 1. 12.2013

27. Theatre forum II. (series of workshops on Contemporary theatre poetics)

Leader: Bc. Denisa Polúchová

Date: 13-15. 12. 2013

Visiting theatre groups in University creative atelier

1. Jaroslav Viňarský: Buticulla: Fool's Figures (Figúry blázna) and Last Step Before (Posledný krok pred)

Date: 6. 4. 2011

2. Mariana Ďurčeková - Ján Luterán: project. wedding (projekt.svadba)

Stanica Žilina-Záriečie (Cultural Node)

Date: 11. 5. 2011

3. Švantner - Ditte - Jurčová: The Bride of the Ridge (Nevesta hôl')

Theatre Poton

Date: 5. 10. 2011

4. Katarína Aulitisová: "Paskudárium"

Theatre Piki Pezinok

Date: 9. 11. 2011

5. Karol Horák: Living Furniture (Živý nábytok)

Students Theatre of Faculty of Arts, Prešov University

Date: 7. 12. 2011

6. Sláva Daubnerová: “M. H. L." 
Theatre P. A. T. and Studio 12 Bratislava

Date: 29. 2. 2012

7. Juraj Benčík: "Pantomimárium"

Theatre s. r. o. Bratislava in cooperation with Theatre a. ha Bratislava

Date: 28. 3. 2012

8. Blaho Uhlár and DISK: The View (Výhl'ad)

Studio Disk - Trnava

Date: 25.4 .2012

9. A group of authors: Protected Area (Chránené územie)

City Theatre - Theatre on Crossroads Banská Bystrica

Date: 3. 10. 2012

10. A group of authors: "Kuca paca"

Theatre with No Home Bratislava

Date: 7. 11. 2012

11. Iveta Škripková: Mocad(r)amas (Mocad(r)ámy)

The Puppet theatre at the Crossroads Banská Bystrica

Date: 5. 12. 2012

Lectures

1. Teaching Peter Scherhaufer's theatre

Lecturer: prof. PhDr. Dagmar Inštitorisová, PhD

Date: 3. 12. 2010

2. Reconstruction of historical poetics

Lecturer: prof. PhDr. Dagmar Inštitorisová, PhD

Date: 10. 3. 2011

3. Ancient Greece Antigone

Lecturer: Mgr. Dáša Čiripová

Date: 23. 6. 2011 and 9. 12. 2011 (for students within the workshop Antigone I.)

4. Scene - phenomenon of the present

Lecturer: Mgr. Bc. Peter Janků, PhD

Date: 2. 5. 2013

5. New circus - art of the global era

Lecturer: Mgr. art. Juraj Benčík

Date: 9. 5. 2013

6. Sarah Kane - authorial Uroboros

Lecturer: Mgr. Dana Gálová, PhD

Date: 16. 5. 2013

7. Regional aspects in creation by in Nitra

Lector: PhDr. Matej Šiška, PhD

Date: 24. 10. 2013

8. About the project Education by Theatre

Lecturer: prof. PhDr. Dagmar Inštitorisová, PhD

Date: 12. 12. 2013

Conferences and colloquiums

1. Antigone - unfinished "trilogy"

Date: 22. 3. 2012

2. Education by theatre - international scientific conference

Date: 21-22. 5. 2013

Excursions
1. Theatres in Žilina: Puppet Theatre Žilina, Stanica Žilina-Záriečie (Cultural Node), Žilina City Theatre

Date: 8. 3. 2011

2. Slovak Chamber Theatre

Date: 11. 4. 2012

3. Theatres in the east of Slovakia: Students Theatre of Faculty of Arts, Prešov University,

The Alexander Duchnovič Theatre, Puppet Theatre Košice, Theatre Kontra Spišská Nová Ves, Spiš Theatre

Date: 3-5. 4. 2013

Festivals

4. The $12^{\text {th }}$ Drama Festival in English "Stories \& Legends of the Slovak Past"

Date: 11. 4. 2011 - 12. 4. 2011

5. The $13^{\text {th }}$ Drama Festival in English

Date: 21. 3. 2012 - 22. 3. 2012

Drama performances

1. The Vampires' Ball (Ples upírov) - school musical First and second premiere: 3. 5. 2011 and 4. 5. 2011

2. Mind (the) Body (Prejst' (si) telom)

Premiere: 27. 2. 2013

3. From the East to the West ( $\mathrm{Z}$ východu na západ)

Premiere: 23. 4. 2013

Publications

Translation: Mgr. Emília Perez, PhD 